\title{
PENGELOLAAN PENDIDIKAN KARAKTER BANGSA BERBASIS BUDAYA JAWA DI TK NEGERI PEMBINA SURAKARTA
}

\author{
Surani, Bambang Sumarjoko, dan Sabar Narimo \\ Program Studi Magister Administrasi Pendidikan \\ Email: surani329@gmail.com
}

\begin{abstract}
This study aimed to describe the character-based education management Javanese culture as well as enabling and inhibiting factors in TK Negeri Pembina Surakarta. This study uses qualitative research, research design using qualitative descriptive method. Implementation of this research is in the TK Negeri Pembina Surakarta. The data used in this study are primary data and secondary data. Source of the data obtained through interviews and documentation. As a guest speaker in this study was the Principal Teachers and Parents / guardians of students. The validity of the data used in this research is triangulation and source triangulation method. Data were analyzed using interactive analysis. Based on the results of data analysis and discussion we concluded that: 1) The management of education-based character of Javanese culture in TK Negeri Pembina Surakarta carried out by adjusting the curriculum and educational materials charged Javanese culture integrates the material elements of the arts, languages and social systems of Javanese culture, delivering materials charged the value of honesty, humility, discipline, courtesy, cooperation, caring, and responsibility; and deliver material which imparts the principles of respect, harmony, character wise and honest, introspective, low self-esteem, as well as upload formungguh and good manners as a form of character Java. 2) The supporting factors in the management of Javanese culture-based character education is education offices and local governments, provision of facilities, committee and parents of students, school management, as well as students coming from the Java community. Factors inhibiting Javanese culture-based education is the lack of standard guidelines for the implementation of educational programs that charged Javanese culture, interests learners to Javanese culture, as well as operate and circumstances on ignorance educators learn less supportive media to use.
\end{abstract}

Keywords: character education, java culture

\begin{abstract}
ABSTRAK
Penelitian ini bertujuan untuk mendeskripsikan pengelolaan pendidikan karakter berbasis budaya Jawa serta faktor pendukung dan penghambat di TK Negeri Pembina Surakarta. Penelitian ini menggunakan jenis penelitian kualitatif, desain penelitian menggunakan metode deskriptif kualitatif. Pelaksanaan penelitian ini adalah di TK Negeri Pembina Surakarta. Data yang digunakan dalam penelitian ini
\end{abstract}


adalah data primer dan data sekunder. Sumber data diperoleh melalui wawancara dan dokumentasi. Sebagai narasumber dalam penelitian ini adalah Kepala Sekolah Guru dan Orang tua / wali siswa. Validitas data yang digunakan dalam penelitian ini adalah triangulasi metode dan triangulasi sumber. Teknik analisis data menggunakan analisis interaktif. Berdasarkan hasil analisis data dan pembahasan diperoleh kesimpulan bahwa: 1) Pengelolaan pendidikan karakter berbasis budaya Jawa di TK Negeri Pembina Surakarta dilaksanakan dengan menyesuaikan pada kurikulum dan materi pendidikan yang bermuatan budaya Jawa mengintegrasikan materi unsur seni, bahasa dan sistem sosial budaya Jawa, menyampaikan materi bermuatan nilai kejujuran, kerendahan hati, kedisiplinan, kesopanan, kerja sama, kepedulian, dan tanggung jawab; dan menyampaikan materi yang menanamkan prinsip hormat, kerukunan hidup, watak arif dan jujur, mawas diri, rendah diri, serta membentuk unggah-ungguh dan tata krama yang baik sebagai wujud budi pekerti Jawa. 2) Faktor pendukung dalam pengelolaan pendidikan karakter berbasis budaya Jawa yaitu dinas pendidikan dan pemerintah daerah, penyediaan fasilitas, komite dan orang tua peserta didik, managemen sekolah, serta peserta didik berasal dari masyarakat Jawa. Faktor penghambat pendidikan berbasis budaya Jawa yaitu belum adanya pedoman baku untuk pelaksanaan program pendidikan yang bermuatan budaya Jawa, minat peserta didik terhadap budaya Jawa, serta kekurangtahuan pendidik mengoperasikan maupun keadaan media belajar yang kurang mendukung untuk digunakan.

Kata Kunci: pendidikan karakter, budaya jawa

\section{PENDAHULUAN}

Membicarakan karakter merupakan hal sangat penting dan mendasar. Orang-orang yang berkarakter kuat dan baik secara individual maupun sosial ialah mereka yang memiliki akhlaq, moral, dan budi pekerti yang baik. Mengingat begitu pentingnya karakter, maka institusi pendidikan memiliki tanggung jawab untuk menanamkannya dalam diri peserta didiknya. Pendidikan karakter dimaknai sebagai suatu perilaku yang di dalam penyelenggaraan pendidikan harus berkarakter dan berpijak dari karakter dasar manusia dari nilai moral yang bersumber dari agama dan dengan sadar mau melaksanakan nilai-nilai tersebut, baik terhadap Tuhan Yang Maha Esa (YME), diri sendiri, sesama, lingkungan, maupun kebangsaan sehingga menjadi insan kamil. Dalam pendidikan karakter di sekolah, semua komponen (stakeholders) harus dilibatkan, termasuk komponen-komponen pendidikan itu sendiri, yaitu isi kurikulum, proses pembelajaran, penilaian, kualitas hubungan, pengelolaan mata pelajaran, sekolah, aktivitas atau kegiatan ekstrakurikuler, pemberdayaan sarana prasarana, pembiayaan, dan etos kerja seluruh warga dan lingkungan sekolah.

Megawangi (2012: 33) mencontohkan bagaimana kesuksesan Cina dalam menerapkan pendidikan karakter sejak awal tahun 1980-an. Menurutnya, pendidikan karakter adalah untuk mengukir akhlak melalui proses knowing the good, loving the good, and acting the good. Yakni, suatu proses pendidikan yang melibatkan aspek kognitif, emosi, dan fisik, sehingga akhlak mulia bisa terukir menjadi habit of the mind, heart, and hands. "Belajar di masa 
kecil ibarat mengukir diatas batu, sedangkan belajar ketika sudah dewasa ibarat mengukir di atas air". Istilah tersbut sangat populer dan memiliki makna yang dalam. istilah tersebut juga mempunyai makna yang sesuai dengan konsep pendidikan anak usia dini yang sangat mementingkan stimulasi sejak dini agar anak dapat belajar banyak dan mengembangkan potensi dan minat yang dimiliki anak yang akan memberikan pengalaman dan kenangan yang begitu kuat terhadap anak, hal ini sangat berbeda ketika kita sudah dewasa apalagi kita menyinggung tentang karakter dan watak yang sudah menjadi kesatuan dalam kepribadian sehingga untuk merubahnya akan jauh lebih sulit. Sehingga penanaman karakter sejak dini menjadi kunci utama dalam membentuk karakter positif anak dan menjadi pondasi kepribadian yang akan menjadi orang yang memiliki karakter kuat.

Pendidikan karakter dapat diintegrasikan pada setiap materi yang disampaikan dalam metode pembelajaran yang ada di tingkat Taman Kanak-Kanak yang meliputi sekurangkurangnya 3 hal yaitu : Pertama Afektif, yang tercermin dalam kualitas keimanan, ketakwaan, akhlaq mulia termasuk budi pekerti luhur serta berkepribadiaan unggul, dan kompetensi estestis. Kedua Kognitif, yang tercermin kepada kwalitas fikir, dan daya intelektualitas untuk menggali dan mengembangkan serta menguasai ilmu pengetahuan dan tekhnologi tentu saja yang berdasar kepada pendidikan nilai, norma dan akhlaq sebagai landasan pendidika karakter. Ketiga Psikomotorik, yang tercermin kepada kemampuan mengembangkan ketrampilan tekhnis, kecakapan praktis, dan kompetensi kinestetis.

Pendidikan karakter di tingkat Taman Kanak-kanak juga sangat terkait dengan manajemen atau pengelolaan sekolah. Pengelolaan sekolah dimaksudkan dengan bagaimana pendidikan karakter direncanakan, dilaksanakan, dan dikendalikan dalam kegiatan-kegiatan disekolah yang meliputi; nilai-nilai yang perlu ditanamkan, muatan kurikulum, pendidikan dan tenaga pendidikan dan komponen terkait lainnya seperti hubungan sekolah dengan wali murid sebagai pendidik anak diluar jam sekolah dengan menggunakan perantara buku penghubung.

Dalam pelaksanaan praktik pendidikan yang ada di Indonesia baik dalam setara pendidikan dasar, menengah maupun tingkat atas, apabila dilihat dari standar nasional pendidikan yang menjadi acuan pengembangan kurikulum 2013, serta implementasi dan penilaian di sekolah, tujuan pembelajaran di tingkat Taman Kanak-kanak sebenarnya sudah dapat dicapai dengan baik melalui metode pembelajaran yang beraneka ragam dan berkembang sesuai dengan tingkat perkembangan anak. Termasuk pendidikan karakterpun sudah mulai dikenalkan dan dimasukkan dalam metode pembelajaran yang ada di tingkat Taman Kanak-kanak. Permasalahannya, pendidikan karakter di tingkat Taman Kanak-kanak masih dalam tingkatan pengenalan dan pembiasaan ketika jam pembelajaran di sekolah, dan belum pada tingkatan implementasi dan tindakan nyata dalam kehidupan sehari-hari baik di rumah maupun dalam aktiftas diluar jam pembelajaran di sekolah.

Guru di Taman Kanak-Kanak Negeri Pembina Surakarta dalam mengajarkan pendidikan karakter budaya Jawa kepada siswanya, mereka tidak hanya memberikan konsep kepada para siswa tentang karakter apa dan mana yang dianggap sesuai oleh masyarakat, tetapi juga berusaha untuk menjalankannya. Bagi guru, pituduh (wejangan) tidak akan berhasil jika hanya diucapkan saja, tanpa dilaksanakan, dan ini sesuai dengan adagium yang muncul dengan istilah "gedhang awoh pakel, ngomong gampang ngelakone angel" (ibarat pisang berbuah mangga, bicara mudah tetapi menjalankannya susah), atau istilah lainnya "gajah 
diblangkoni, bisa kojah ora bisa nglakoni" (seperti gajah yang diberi blangkon, hanya bicara tidak pernah melaksanakan apa yang diucapkannya).

Sementara itu, terkait dengan peran guru dalam menerapkan pendidikan karakter berbasis budaya Jawa pada anak usia dini di Taman Kanak-Kanak Negeri Pembina Surakarta yang merupakan program unggulan, tentunya akan disesuaikan dengan budaya Jawa, tentang unggah-ungguh/tata krama yang dapat dimasukkan dengan nilai-nilai karakter yang ada. Dalam teori perkembangan, anak akan tumbuh dan berkembang dengan baik tidak saja cukup mengandalkan potensi yang dibawanya secara genetik akan tetapi juga sangat ditunjang oleh faktor lain yaitu lingkungannya sebagaimana dinyatakan oleh John Lock (1632-1704) melalui teori empirismenya yang beranggapan bahwa "manusia lahir dalam keadaan tabularasa, putih bersih bagaikan kertas yang belum ditulisi. Lingkunganlah yang membentuk seseorang menjadi manusia seperti dia pada waktu dewasa" (Irwanto, CS dalam Sofiah, 2012: 212).

Tujuan penelitian ini adalah: 1) Mendeskripsikan pengelolaan pendidikan karakter berbasis budaya Jawa di TK Negeri Pembina Surakarta. 2) Mendeskripsikan faktor pendukung dan penghambat pengelolaan pendidikan karakter berbasis budaya Jawa di TK Negeri Pembina Surakarta.

\section{METODE PENELITIAN}

Jenis penelitian ini adalah penelitian deskriptif. Penelitian diskriptif adalah penelitian yang dilakukan untuk mengetahui nilai variabel mandiri, baik satu variabel atau lebih (independen) tanpa membuat perbandingan, atau menghubungkan dengan variabel yang lain (Sugiyono, 2012: 115). Desain yang digunakan dalam penelitian ini adalah desain penelitian deskriptif kualitatif, yaitu penelitian yang berlandaskan pada filsafat postpositivisme, digunakan untuk meneliti pada kondisi objek yang alamiah, dimana peneliti adalah sebagai instrumen kunci, teknik pengumpulan data dilakukan secara triangulasi (gabungan), analisis data bersifat induktif/kualitatif dan hasil penelitian kualitatif lebih menekankan makna dari pada generalisasi (Sugiyono, 2010: 9). Deskripsi dalam penelitian ini mengenai pengelolaan pendidikan karakter berbasis budaya Jawa di TK Negeri Pembina Surakarta.

Pelaksanaan penelitian ini adalah di TK Negeri Pembina Surakarta. TK Negeri Pembina Surakarta saat ini memiliki jumlah Kelompok Belajar sebanyak 6 Kelompok Belajar dan 1 Kelompok Bermain. Adapun jumlah tenaga pendidik sebanyak 11 orang, 1 kepala sekolah dan 8 orang karyawan. Validitas data yang digunakan dalam penelitian ini adalah triangulasi sumber dan triangulasi teknik. Teknik analisa data yang digunakan dalam penelitian tersebut adalah model analisis interaktif (model saling terjalin). Dalam model analisis interaktif, tiga komponen yakni reduksi data, sajian data dan penarikan kesimpulan dilakukan berbentuk interaksi dengan proses pengumpulan data sebagai proses siklus.

\section{HASIL DAN PEMBAHASAN}

\section{Pengelolaan Pendidikan Karakter Berbasis Budaya Jawa di TK Negeri Pembina Surakarta}

Penyelenggaraan pendidikan berbasis budaya Jawa merupakan salah satu cara untuk menyampaikan muatan budaya Jawa melalui pendidik anak-anak. Melalui pendidikan ini dapat disampikan berbagai unsur, nilai dan budi pekerti serta pengembangan minat dan bakat 
peserta didik dalam keterampilan seni budaya Jawa. Konsep pendidikan berbasi budaya Jawa ini mendukung dalam pembentukan karakter peserta didik melalui peningkatan kemampuan pengetahuan yang diiringi penanaman budi pekerti dan nilai-nilai budaya Jawa. Selain itu, pendidikan ini juga salah satu wujud pelestarian budaya Jawa melalui pengenalan sejak dini terhadap peserta didik.

TK Negeri Pembina Surakarta menunjukkan implementasi pendidikan berbasis budaya melalui berbagai komponen pendidikan. Pengertian pendidikan secara khusus menurut Dewantara (2011:13) adalah salah satu usaha untuk memberian segala nilai-nilai kebatinan yang ada dalam hidup rakyat yang berbudaya kepada setiap generasi, tidak hanya berupa pemeliharaan akan tetapi juga dapat dimaksud memajukan serta mengembangkan kebudayaan menuju kearah keluhuran hidup manusia. Hal tersebut menununjukkan bahwa seharusnya pendidikan tidak hanya memelihara kebudayaan tetapi bahkan memajukan dan mengembangkan tanpa meninggalkan karakteristik budaya itu sendiri. Inilah yang coba direalisasikan oleh TK Negeri Pembina Surakarta dalam pendidikannya. Unsur-unsur budaya Jawa sebagai kearifan budaya lokal digunakan untuk memenuhi kebutuhan peserta didik sesuai kodrat alamnya selain dalam hal pengetahuan umum.

TK Negeri Pembina Surakarta ini melaksanakan sistem among sebagai sistem pendidikan. Sistem among merupakan pencerminan dari tut wuri handayani pada semboyan pendidikan Ki Hadjar Dewantara. Seperti pengertian sistem among pada pasal 12 Piagam dan Peraturan Besar Persatuan Taman Siswa (Fudyartanta, 1986: 12) yang dirumuskan sebagai suatu sistem pendidikan yang berjiwa kekeluargaan dan bersendikan dua dasar, yaitu: (1) Kodrat Alam, sebagai syarat untuk mencapai kemajuan dengan secepat-cepatnya dan sebaik-baiknya; dan (2) Kemerdekaan, sebagai syarat untuk menghidupkan dan menggerakkan kekuatan lahir batin peseta didik agar dapat memiliki pribadi yang kuat dan dapat berfikir serta bertindak merdeka. Sistem tersebut menurut berlakunya juga disebut sistem "Tutwuri Handayani”.

Sekolah ini menerapkan sistem dimana peran pendidik sebagai pengawas atau pengamat memberikan pembelajaran tanpa paksaan dan membiarkan peserta didik berkembang sebagaimana mestinya sesuai jalur yang benar. Hal ini seperti yang dikemukakan oleh Dewantara (2011: 13) bahwa pendidikan Tamansiswa tidak memakai syarat paksaan. Opvoeding atau paedagogiek semaksud dengan pengertian momong, among dan ngemong. Itulah yang digunakan sebagai dasar pendidikan Tamansiswa. Caranya tidaklah memaksa walaupun hanya sekedar memimpin kadang juga tidak perlu. Kita hanya perlu mencampuri kehidupan anak kalau berada di jalan yang salah. Bahasa momong, among dan ngemong merupakan istilah Jawa yang menggambarkan cara mendidik anak-anak di masyarakat Jawa. Sehingga sistem among juga merupakan wujud budaya pendidikan masyarakat Jawa.

Di sekolah ini pendidik menjalankan perannya sebagai pemimpin ketika menyampaikan pembelajaran, sebagai teman yang mampu memberikan motivasi dan memposisikan diri sebagai pengamat yang mendukung ketika peserta didik mengaplikasikan ilmu yang diperoleh. Hal ini senada dengan pernyataan Purwanto (2011: 63) mengungkapkan bahwa dalam sistem among setiap pamong atau pendidik sebagai seorang pemimpin dalam proses pendidikan diwajibkan bersikap 1) Ing Ngarsa Sung Tuladha yang artinya jika pendidik sedang berada di depan maka hendaknya memberikan contoh teladan yang baik terhadap peserta didiknya, 2) Ing Madya Mangun Karsa yang berarti jika pendidik sedang berada di tengah-tengah peserta 
didiknya maka hendaknya pendidik dapat mendorong kemauan atau kehendak peserta didik dan membangkitkan hasrat peserta didik untuk berinisiatif dan bertindak, dan 3) Tut Wuri yang berarti mengikuti dari belakang dan Handayani yang berarti mendorong, memotivasi atau membangkitkan semangat.

Sistem pendidikan sekolah ini merupakan sistem pendidikan yang berpusat pada peserta didik dimana seluruh usaha pendidikan bertujuan untuk perkembangan kemampuan peserta didik secara maksimal. Melalui penerapan sistem among dikembangkan pendidikan berbasis budaya Jawa ke berbagai hal yaitu: (1) Penerapan pada visi, misi dan tujuan sekolah; (2) Penyesuaian pada kurikulum dan materi pendidikan; (3) Pengajaran melalui program pendidikan; (4) Pemodelan dan pembiasaan dari pendidik; dan (5) Pengkondisian sarana dan lingkungan sekolah.

TK Negeri Pembina Surakarta melakukan penyesuaian pada kurikulum dan materi pendidikan sehingga lebih kondusif dalam menyampaikan muatan budaya Jawa. Selain itu, sekolah ini juga memaksimalkan penyampaian materi yang bermuatan budaya Jawa. Materi budaya Jawa ini dapat berupa unsur-unsur, nilai maupun budi pekerti Jawa. Nilai dan budi pekerti Jawa tidak disampaikan melalui pelajaran melainkan terintegrasi dalam semua pelajaran. Hal ini seperti yang dikemukakan oleh Endraswara (2006: 5) bahwa berbagai nilai dan budi pekerti akan disisipkan secara integrated pada materi pelajaran lain. Jadi, budi pekerti bukanlah mata pelajaran yang berdiri sendiri karena budi pekerti adalah sikap dan perilaku afektif yang bersifat afekti. Sedangkan unsur-unsur seni, bahasa dan sosial dari budaya Jawa direalisasikan kedalam beberapa pelajaran dan ekstrakulikuler.

Unsur yang disampaikan melalui program didominasi oleh seni budaya Jawa. Peranan istimewa dari seni budaya ini bukan dimaksudkan untuk mendukung pendidikan atau pengajaran umum sehingga dihasilkan manusia yang tidak hanya terdidik nalar atau pengetahuannya saja tapi juga keluhuran dari keindahan serta kehalusan dari seni budaya itu sendiri.

Selain itu, unsur bahasa dan sistem sosial juga disampaikan melalui program pendidikan yang menyampaikan kaweruh basa Jawa serta unggah-ungguh atau tata krama. Melalui program ini peserta didik bertambah pengetahuan dan pemahamannya terhadap budaya Jawa terutama bahasa Jawa serta sebagai salah satu bentuk pelestarian budaya. Bahasa memiliki peranan yang penting pada suatu budaya tidak terkecuali budaya Jawa. Identitas suatu budaya salah satunya terlihat dari bahasa yang digunakan. Dalam pelaksanaannya sekolah ini memang mendukung penggunaan bahasa daerah atau bahasa Jawa tapi juga terbuka dalam mempelajari bahasa lain seperti bahasa Indonesia dan bahasa Inggris untuk menambah pengetahuan dan wawasan peserta didik.

Nilai-nilai budaya Jawa yang disampaikan dan terlihat dalam penyelenggaraan pendidikan lebih pada nilai kejujuran, kerendahan hati, kedisiplinan, kesopanan, kerja sama, kepedulian, dan tanggung jawab. Nilai-nilai budaya Jawa tadi ditonjolkan melalui pemaknaan terhadap filosofi Jawa yang ada pada syair tembang, dongeng, gerakan tari, maupun berbagai kegiatan pada pembelajaran yang berkaitan. Nilai luhur budaya Jawa yang dimaksud tersebut identik dengan pendidikan karakter yang ditanamkan pada peserta didik melalui berbagai strategi.

Dalam penyelenggaraan pendidikan berbasis budaya Jawa TK Negeri Pembina Surakarta menanamkan prinsip hormat, kerukunan hidup, watak arif dan jujur, mawas diri, rendah diri, 
serta membentuk unggah-ungguh dan tata krama yang baik. Prinsip-prinsip tadi merupakan prinsip yang dipegang oleh masyarakat budaya Jawa untuk membentuk budi pekerti dan akhlak mulia sebagai bentuk pendidikan moral masyarakat Jawa. Pada masyarakat Jawa prinsip hormat sangat dijunjung dan menjadi prinsip utama yang diajarkan pada anakanaknya. Prinsip hormat yang dimaksudkan lebih pada menghormati lain terutama orang tua. Prinsip yang selanjutnya kerukunan hidup yang merujuk pada keselarasan sosial dari budaya saling menghargai. Watak arif dan jujur, mawas diri, serta rendah diri merupakan bentuk penanaman budi pekerti menuju keutamaan hidup bagi masyarakat Jawa. Sedangkan untuk unggah-ungguh dan tata krama merupakan suatu bentuk aturan yang harus diaplikasikan untuk mendidik kesopanan pada masyarakat Jawa (Endraswara, 2006: 23).

Sekolah ini mewujudkan muatan budaya Jawa pada pengajaran program intrakulikuler yaitu seni tari, seni suara daerah, dan batik. Sedangkan untuk ekstrakulikuler sekolah ini memiliki program ekstra kulikuler wajib bahasa Jawa, ekstra kulikuler pilihan karawitan dan dolanan anak. Melalui berbagai program ini ditingkatkan kemampuan peserta didik dalam pengetahuan dan keterampilan budaya Jawa. Dalam pelaksanaannya beberapa programprogram pendidikan berbasis budaya Jawa sudah dapat menyampaikan materi budaya Jawa dengan baik dan menyampaikan maksud, nilai serta budi pekerti yang terkandung dalam materi tersebut. Namun masih ada beberapa program yang hanya berorientasi pada pengetahuan, keterampilan dan lomba saja walaupun sebenarnya program ini merupakan peluang untuk pendidikan karakter. Pada program dolanan anak dan karawitan sebenarnya bisa dipetik berbagai budi pekerti dan nilai-nilai kearifan budaya Jawa dari sejarah, tujuan dan fungsi dari berbagai materi yang disampaikan. Tapi sebagai pengenalan budaya Jawa sejak dini untuk menumbuhkan rasa cinta terhadap budaya bangsa sekolah ini sudah memaksimalkan sumberdaya yang ada melalui berbagai program-program tersebut.

Dari hasil pelaksanaan program didapati bahwa peserta didik cukup tertarik dengan berbagai program yang menyampaikan budaya Jawa. Ketertarikan itu direalisasikan melalui keaktifan mereka dalam mengikuti program sehingga menghasilkan prestasi yang membanggakan terutama dalam bidang budaya Jawa seperti panembromo, macapat dan dolanan anak. Melalui program pendidikan berbasis budaya ini terlihat perebedaan karakteristik peserta didik sekolah ini dengan sekolah lain. Peserta didik sekolah ini lebih memiliki pengetahuan dan keterampilan budaya Jawa serta sopan santun dalam bergaul terutama dengan orang yang lebih tua.

Pelaksanaan pendidikan berbasis budaya Jawa juga dibiasakan melalui pemodelan dan pembiasaan dari pendidik dalam hal bersosialisasi di lingkungan sekolah berdasarkan unggah-ungguh, tata krama dan nilai budaya Jawa. Pemodelan yang dilakukan oleh pendidik secara langsung antara lain dalam hal kerapihan berpakaian sopan santun dalam tingkah laku dan tutur kata. Selain itu pendidik juga memberikan contoh datang tepat waktu dan berjabat tangan saat bertemu dengan peserta didik maupun wali atau orang tua sebagai langkah awal pembiasaan. Seperti yang disampaikan oleh Endraswara (2006: 15), bahwa sebagai warisan budaya, nilai, sosialisasi budi pekerti jelas diperlukan figur dan contoh-contoh yang jelas dari generasi sebelumnya. Melalui tauladan dan media yang menarik, otomatis seseorang akan dapat menyerap konsep-konsep budi pekerti dan pada gilirannya dapat mengaplikasikan. 
Selain itu pendidik juga melakukan pembiasaan kepada peserta didik yang mengarahkan untuk aplikasi nilai-nilai dan budi pekerti dari budaya Jawa. Kegiatan pembiasaan yang dilakukan antara lain: (1) Bersalaman sebelum masuk ruang kelas dan sebelum pulang peserta didik menjadi lebih disiplin dan teratur; (2) Menggunakan bahasa Jawa yang halus untuk berkomunikasi dengan pendidik maupun antar peserta didik terutama saat pelajaran bahasa Jawa; dan (3) Hal-hal kecil seperti ketika ingin meminta izin kebelakang. Pendidik juga membiasakan peserta didik untuk mengaplikasikan unggah-ungguh dan tata krama selama pelajaran berlangsung maupun diluar kegiatan pembelajaran melalui arahan yang nyata dan jelas misalnya bersalaman dengan dengan pendidik saat datang dan pulang sekolah. Pembiasaan tata krama juga dilakukan di berbagai kesempatan melalui arahan langsung kepada peserta didik.

Selanjutnya, implementasi pendidikan berbasis budaya Jawa juga dilakukan melalui pengkondisian sarana prasarana dan lingkungan sekolah. Sarana yang dimaksimalkan untuk mendukung program pendidikan berbabasis budaya Jawa adalah LCD proyektor, tape recorder dan speaker. Sedangkan sarana pendukungnya meliputi ruang kelas dan halaman sekolah.

\section{Faktor Pendukung dan Penghambat Pendidikan Berbasis Budaya Jawa.}

Dalam pelaksanaan pendidikan berbasis budaya Jawa ditemukan berbagai hal yang menjadi faktor mendukung maupun menghambat. Hal yang menjadi faktor pendukung yang di miliki sekolah ini yang pertama adalah dari latar belakang sekolah yang sejak awal memang terkonsep menyenggarakan pendidikan dengan muatan pengetahuan yang didukung muatan budaya lokal.

Dukungan berasal dari komite dan orang tua peserta didik dalam memaksimalkan penyelenggaraan pendidikan berbasis budaya Jawa. Bentuk dukungan dari komite dan orang tua beragam dalam hal materiil dan non materiil. Ada orang tua yang masukkan peserta didik ke sanggar hingga ikut terjun langsung membantu peserta didik latihan bila akan mengikuti lomba. Managemen sekolah didukung dengan adanya kepala sekolah yang memiliki kemampuan dan pengalaman yang mumpuni sebagai kepala sekolah serta latar belakang budaya Jawa. Kompetensi sosial budaya dari pendidik dengan latar belakang budaya Jawa yang cukup juga mendukung penyelenggaraan pendidikan berbasis budaya Jawa di sekolah ini. Tingkat kemampuan pendidik di sekolah ini beragam tapi saling mendukung dalam pelaksanaan pendidikan berbasis budaya Jawa dengan berbagai pelatihan, saling sharing dan mencari referensi untuk meningkatkan kemampuan.

Hal pendukung dari peserta didik yaitu hampir $75 \%$ peserta didik berasal dari masyarakat Jawa. Karakteristik peserta didik secara umum adalah peserta didik yang aktif dengan rasa ingin tahu yang tinggi dengan sikap sopan dan santun memudahkan pendidik untuk menyampaikan materi budaya Jawa.

Selain faktor pendukung juga terdapat berbagai hal yang menghambat pelaksanaan pendidikan berbasis budaya Jawa di TK Negeri Pembina Surakarta. Faktor yang menghambat pertama adalah belum ada pendidik yang benar-benar ahli dalam seni budaya batik untuk menjadi pengampu pelajaran batik. Selanjutnya belum semua pendidik berhasil memaksimalkan penyampaian materi budaya Jawa kepada peserta didik dikarenakan belum 
adanya pedoman baku untuk pelaksanaan beberapa program pendidikan budaya Jawa. Pendidik juga harus mengembangkan sendiri-sendiri sesuai kemampuan yang dimiliki.

Dari peserta didik pelaksanaan pembelajaran sering terhambat oleh minatnya terhadap budaya Jawa yang sering berubah-ubah. Kendala lain meskipun mayoritas peserta didik berasal dari masyarakat Jawa namun pengetahuan budaya Jawanya masih sangat kurang. Selanjutnya, kekurangsiapan pendidik mengembangkan materi untuk peserta didik. Pendidik harus ekstra menyesuaikan materi agar bisa diterima dan dimaksimalkan oleh seluruh peserta didiknya.

Dalam hal fasilitas, penggunaan media pembelajaran bahasa Jawa oleh pendidik kurang maksimal. Hal ini bisa disebabkan oleh kekurangtahuan pendidik mengoperasikan maupun keadaan media yang kurang mendukung untuk digunakan. Mayoritas program pendidikan berbais budaya Jawa di sekolah ini merupakan program yang mengajarkan seni budaya Jawa sehingga memerlukan peralatan pentas untuk memaksimalkan pelaksananya. Beberapa hambatan tersebut lebih karena sekolah ini merupakan sekolah swasta sehingga terkendala dana dalam penyediaan hal-hal pendukung pendidikan berbasis budaya Jawa.

Upaya yang dapat dilakukan untuk mengurangi faktor penghambatan pelaksanaan program pendidikan berbasis budaya Jawa adalah: (1) Menyelenggarakan pelatihan budaya Jawa untuk pendidik dengan bantuan dinas pendidikan maupun pihak dari luar sekolah; (2) Membuat pedoman pelaksanaan beberapa program pendidikan budaya Jawa dengan bantuan pihak luar yang ahli sebagai acuan; (3) Peningkatan minat peserta didik melalui pengenalan dan pembelajaran yang menarik; dan (4) Berkoordinasi dengan dinas pendidikan atau pihak terkait lainnya untuk peningkatan fasilitas belajar budaya Jawa.

\section{PENUTUP}

Pengelolaan pendidikan karakter berbasis budaya Jawa di TK Negeri Pembina Surakarta dilaksanakan dengan menyesuaikan pada kurikulum dan materi pendidikan yang bermuatan budaya Jawa mengintegrasikan materi unsur seni, bahasa dan sistem sosial budaya Jawa, Menyampaikan materi bermuatan nilai kejujuran, kerendahan hati, kedisiplinan, kesopanan, kerja sama, kepedulian, dan tanggung jawab; dan menyampaikan materi yang menanamkan prinsip hormat, kerukunan hidup, watak arif dan jujur, mawas diri, rendah diri, serta membentuk unggah-ungguh dan tata krama yang baik sebagai wujud budi pekerti Jawa.

Faktor pendukung dan penghambat dari implementasi pendidikan berbasis budaya Jawa di TK Negeri Pembina Surakarta sangat beragam. Faktor pendukung yang dimiliki sekolah ini adalah: 1) peraturan dari dinas dan pemerintah daerah serta dukungan mengenai penyelenggaraan pendidikan berbasis budaya, 2) penyediaan fasilitas, dana dan tenaga pendidik pendukung dari dinas pendidikan, 3) komite dan orang tua peserta didik juga mendukung dalam hal materiil maupun non materiil, 4) managemen sekolah dengan kepala sekolah yang berkompeten, 5) Mayoritas peserta didik berasal dari masyarakat Jawa. Sedangkan faktor penghambat implementasi pendidikan berbasis budaya Jawa di TK Negeri Pembina Surakarta adalah 1) belum adanya pedoman baku untuk pelaksanaan program pendidikan yang bermuatan budaya Jawa, 2) minat peserta didik terhadap budaya Jawa yang sering berubah-ubah, 3) kekurangtahuan pendidik mengoperasikan maupun keadaan media belajar yang kurang mendukung untuk digunakan. 
ISSN: $1907-4034$

\section{DAFTAR PUSTAKA}

Dewantara, K.H. 2011. Karya Ki Hadjar Dewantara Bagian Pertama: Pendidikan. Yogyakarta: Majelis Luhur Persatuan Taman Siswa.

Endraswara, S. 2006. Metode, Teori, Teknik, Penelitian Kebudayaan Ideologi, Epsitemologi, dan Aplikasi. Sleman : Pustaka Widyatama.

Megawangi, R. 2012, Pendidikan Karakter; Solusi Tepat Untuk Membangun Bangsa, Jakarta: Indonesia Heritage Foundation.

Nugroho, T. 2011, Implementasi Nilai-Nilai Dasar Pendidikan Karakter Bangsa Dalam Pembelajaran Matematika Di SMK Muhammadiyah 4 Surakarta Kelas XII Tahun Pelajaran 2010/2011, Prodi Pendidikan Matematika, Universitas Muhammadiyah Surakarta.

Pawito. 2010. Penelitian komunikasi kualitatif. Yogyakarta: PT LkiS Pelangi. Aksara.

Purwanto, M.N. 2011. Ilmu Pendidikan Teoritis dan Praktik. Bandung: PT Remaja Rosdakarya

Samanim, M. dan Hariyanto, 2012, Konsep dan Model Pendidikan Karakter, Bandung: PT Remaja Rosda Karya.

Sofiah, 2012, Pendampingan Orangtua dalam Upaya Melindungi Anak dari Bahaya Kecanduan Teknologi Komunikasi, Surakarta: Jurnal Komunikasi Massa Vol. 6 No. 2 , Juli 2012, ISSN: 1411-268X.

Sugiyono. 2011. Metode Penelitian Kuantitatif, kualitatif dan $R \&$ D. Bandung: Alfabeta

Sutopo, HB. 2010. Metodologi Penelitian Kualitatif. Surakarta. Sebelas Maret University Press.

Zubaedi, 2011, Desain Pendidikan Karakter Konsepsi dan Aplikasinya dalam Lembaga Pendidikan, Jakarta: Kencana.

Zulkifli, 2011, Psikologi Perkembangan, Bagian Perkembangan dalam Masa Kanak-Kanak, Bandung: Remaja Rosdakarya. 